\title{
VARIABEL PERTUMBUHAN EKONOMI, BELANJA DAERAH, INVESTASI, KURS, DAN KRISIS EKONOMI DALAM PEREKONOMIAN JAKARTA 1987-2017
}

\author{
Oleh: \\ Yurianto \\ Badan Pengembangan Sumber Daya Manusia \\ Provinsi DKI Jakarta \\ Email: \\ yuribpsdm@gmail.com
}

\begin{abstract}
The economy of Jakarta is the largest contributor to the national economy, and greatly affects the national economy. The research objective is to identify the variables of economic growth, regional spending, investment, exchange rates and to identify the effects of regional spending variables, investment, exchange rates, and the economic crisis on economic growth. This study uses descriptivequantitative analysis and multiple linear regression methods. The economic growth of Jakarta in the 1987-2017 period tends to increase. The 1998 economic crisis has corrected economic growth. The ratio of direct expenditure to total expenditure and investment has a positive and significant effect on economic growth. Exchange rate depreciation has a negative relationship with economic growth. The economic crisis has a negative effect on economic growth. It was recommended to the TAPD (Regional Government Budget Team) Jakarta to allocate more direct expenditure than indirect expenditure
\end{abstract}

Keywords: Expenditure, Constructive, Exchange Rate, Economic Growth 


\begin{abstract}
ABSTRAK
Perekonomian Jakarta penyumbang terbesar ekonomi nasional, dan sangat memengaruhi perekonomian nasional. Tujuan penelitian adalah mengidentifikasi variabel pertumbuhan ekonomi, belanja daerah, investasi, kurs dan mengidentifikasi pengaruh varaiabel belanja daerah, investasi, kurs, dan krisis ekonomi terhadap pertumbuhan ekonomi. Penelitian ini menggunakan analisis deskriptif-kuantitatif dan metode regresi linier berganda. Pertumbuhan ekonomi Jakarta periode 1987-2017 cenderung meningkat. Krisis ekonomi 1998 telah mengoreksi pertumbuhan ekonomi. Rasio belanja langsung terhadap total belanja dan investasi mempunyai pengaruh positif dan signifikan terhadap pertumbuhan ekonomi. Depresiasi nilai tukar mempunyai hubungan negatif terhadap pertumbuhan ekonomi. Krisis ekonomi berpengaruh negatif terhadap pertumbuhan ekonomi. Direkomendasikan kepada TAPD (Tim Anggaran Pemerintah Daerah) Jakarta agar mengalokasikan belanja langsung lebih besar dari belanja tidak langsung.
\end{abstract}

Kata kunci: belanja, konstruktivistik, kurs, pertumbuhan ekonomi

\title{
A. LATAR BELAKANG
}

Berdasarkan Undang-Undang Nomor 29 tahun 2007 tentang Pemerintahan Provinsi Daerah Khusus Ibukota Jakarta sebagai Ibukota Negara Kesatuan Republik Indonesia dinyatakan bahwa Provinsi Daerah Khusus Ibukota Jakarta dengan kedudukannya sebagai Ibukota Negara Kesatuan Republik Indonesia memiliki fungsi dan peran yang penting dalam mendukung penyelenggaraan pemerintahan Negara Kesatuan Republik Indonesia. Dalam konteks perekonomian, DKI Jakarta menjadi kontributor terbesar terhadap ekonomi nasional. Ini mengandung arti bahwa perekonomian Ibu Kota sangat berpengaruh terhadap perekonomian nasional.

Pertumbuhan ekonomi merupakan salah satu indikator yang lazim digunakan dalam keberhasilan pembangunan daerah sehingga pencapaian pertumbuhan ekonomi yang stabil dan berkelanjutan menjadi salah satu tujuan pembangunan daerah. Menurut penelitian (Ginting \& Dewi, 2013) bahwa pertumbuhan ekonomi berpengaruh signifikan dalam mengurangi kemiskinan, namun magnitude pengaruh tersebut relatif tidak besar. Sedangkan penelitian yang dilakukan (Widada et al., 2014) menemukan bahwa pertumbuhan ekonomi kabupaten/kota hasil pemekaran dipengaruhi variabel belanja pemerintah, infrastruktur, dan tenaga kerja secara positif dan signifikan.

Ini menunjukkan bahwa pertumbuhan ekonomi penting dalam pembangunan daerah dan kenerjanya dipengaruhi oleh berbagai faktor termasuk dalam hal ini besarnya belanja daerah pada APBD. Menurut (Undang-Undang Nomor 17 Tahun, 2003) bahwa kekuasaan pengelolaan keuangan daerah dilaksanakan oleh kepala satuan kerja pengelola keuangan daerah pada pemerintah daerah selaku pejabat pengelola APBD. Pada level operasional pada penyusunan APBD, dibentuk TAPD (Tim Anggaran Pemerintah Daerah) sesuai dengan amanat (Peraturan Menteri 
Dalam Negeri Nomor 13, 2006) tentang Pedoman Pengelolaan Keuangan Daerah. TAPD dipimpin oleh Sekretaris Daerah. Adapun tugasnya adalah menyiapkan serta melaksanakan kebijakan kepala daerah dalam rangka penyusunan APBD. Artinya bahwa penyusunan APBD menjadi penting dalam menentukan besarnya alokasi belanja daerah. Alokasi belanja daerah pada APBD menentukan laju pertumbuhan ekonomi.

Selain besarnya anggaran belanja daerah, hasil penelitian (Pridayanti, 2014) menyatakan bahwa variabel nilai tukar berpengaruh negatif terhadap pertumbuhan ekonomi di Indonesia. Variabel lain yang berpengaruh terhadap perekonomian daerah dan sering dikaji oleh para peneliti perekonomian adalah peran variabel investasi. Menurut (Wahyuni et al., 2014) bahwa investasi berpengaruh positif dan signifikan terhadap pertumbuhan ekonom di kabupaten/kota di Provinsi Bali. Sejalan hal ini, penelitian (Sari \& Fakhruddin, 2016) bahwa investasi sumber daya manusia dan pengeluaran pemerintah baik secara parsial maupun simultan berpengaruh terhadap pertumbuhan ekonomi di Indonesia. Ini menyimpulkan bahwa investasi merupakan faktor utama pertumbuhan ekonomi suatu wilayah.

Penelitian (Fajri, 2016) menunjukkan bahwa pertumbuhan ekonomi tidak dipengaruhi secara signfikan oleh belanja modal di provinsi-provinsi di Sumatera. Berbeda dengan Fajri, (Natalia et al., 2019) menemukan bahwa dengan menggunakan metode analisis regresi berganda hasil penelitiannya menunjukkan bahwa pertumbuhan ekonomi di Provinsi Sulawesi Utara dipengaruhi variabel belanja modal. Mendasarkan pada penelitian tersebut di atas, selanjutnya bagaimana perilaku variabel-variabel tersebut terhadap perekonomian Jakarta. Untuk mengetahui perilaku tersebut diperlukan kajian pengaruh vaiabel tersebut terhadap perekonomian Jakarta dengan mengkhususkan pada periode 1987 sampai dengan 2017.

Sejalan dengan hal ini maka menjadi penting untuk melakukan identifikasi faktor -faktor yang memengaruhi pertumbuhan ekonomi DKI Jakarta. Hal ini mengingat perekonomian Jakarta penting dalam perekonomian nasional. Dengan mencermati uraian di atas tampaknya sangat penting untuk mengkaji beberapa isu penting dan strategis, yaitu bagaimana perilaku variabel pertumbuhan ekonomi, belanja daerah, investasi, nilai tukar rupiah terhadap dolar Amerika dan krisis ekonomi 1998 pada perekonomian Jakarta pada periode 1987-2017, bagaimana pola hubungan kausatif antara kelima variabel tersebut, faktor-faktor apa yang memengaruhi secara signifikan terhadap pertumbuhan ekonomi Jakarta pada periode tahun 1987-2017.

Sejalan dengan kondisi ini maka penelitian ini bertujuan untuk mendeskripsikan dan menganalisis perkembangan pertumbuhan ekonomi, belanja daerah, investasi, nilai tukar rupiah terhadap dolar Amerika Serikat (IDR/USD), mengidentifikasi dan menganalisis variabel rasio belanja langsung daerah terhadap total belanja terhadap pertumbuhan ekonomi DKI Jakarta periode 1987-2017, mengidentifikasi pengaruh variabel investasi, kurs, dan krisis ekonomi 1998 terhadap pertumbuhan ekonomi DKI Jakarta periode 1987-2017

\section{B. KAJIAN PUSTAKA}


Pertumbuhan ekonomi suatu daerah dipengaruhi oleh banyak faktor. Salah satu teori pertumbuhan ekonomi neo-klasik adalah Model Solow-Swan (1956) dalam (Kurniawan et al., 2015) yang menggunakan variabel pertumbuhan penduduk, akumulasi kapital, knowledge atau the effectiveness (eksogen), dan besarnya output yang saling berinteraksi sebagai variabel penjelas. Dalam Model ini masalah teknologi dianggap fungsi dari waktu. Waktu tidak masuk dalam fungsi produksi secara langsung, tetapi hanya melalui output $(\mathrm{Y})$, capital $(\mathrm{K})$, labor $(\mathrm{L})$ dan knowledge atau the effectiveness tenaga kerja (A). Konsep ini diformulasikan sebagai berikut.

$$
\boldsymbol{Y}(\boldsymbol{t})=\boldsymbol{F}[\boldsymbol{K}(\boldsymbol{t}), \boldsymbol{L}(\boldsymbol{t}), \boldsymbol{A}(\boldsymbol{t})]
$$

Secara ringkas dikatakan bahwa dengan knowledge yang baik akan meningkatkan produktivitas faktor input. Proses produksi akan semakin efisien dan faktor input akan lebih produktif. Dengan demikian knowledge dapat meningkatkan aktivitas perekonomian dan akhirnya akan mendorong pembangunan daerah. Ini menunjukkan bahwa akumulasi kapital dan tenaga kerja akan efisien, efektif dan produktif seiring berjalannya waktu sepanjang kualitas dan kuantitas knowledgenya bertambah. Ini menunjukkan bahwa faktor peningkatan kualitas sumber daya manusia menjadi sangat penting dalam mendorong pertumbuhan ekonomi daerah.

Untuk meningkatkan kualitas sumber daya manusia sebagai penentu kebijkan pembangunan daerah menjadi mendesak. Pelatihan, pendidikan dan pendampingan menjadi salah satu solusi penting dalam hal ini. Untuk mengimplementasikan hal ini diperlukan anngaran yang memadai. Alokasi belanja yang menucukupi, memadai dan tepat sasaran menjadi kunci peningkatan kualitas sumber daya manusia.

Berkaitan dengan alokasi belanja, kebijakan alokasi belanja modal berpengaruh positif terhadap investasi swasta. Artinya alokasi belanja modal yang tepat akan mendorong investasi. Analog dengan pemikiran di atas maka belanja rutin dan belanja pembanngunan akan berpengaruh secara signifikan dan positif terhadap aktivitas perekonomian daerah. Kemampuan belanja daerah Jakarta diuraikan pada APBD Pemerintah Provinsi DKI Jakarta. APBD merupakan Anggaran Pendapatan, dan Belanja Daerah (APBD) yang pada dasarnya adalah rencana keuangan tahunan pemerintah daerah di Indonesia yang disetujui oleh Dewan Perwakilan Rakyat Daerah. APBD ditetapkan dengan Peraturan Daerah. Yang dimaksud dengan tahun anggaran APBD adalah masa satu tahun, yaitu dari tanggal 1 Januari sampai dengan tanggal 31 Desember tahun bersangkutan. Secara ringkas dapat dikatakan bahwa besarnya APBD dapat dijadikan tolak ukur keberhasilan daerah dalam menggerakan potensi perekonomian daerahnya.

Menurut (Zuhroh, 2018) anggaran daerah dapat digunakan ukuran akan besarnya belanja rutin dan belanja pembangunan. Hal ini dalam istilah Permendagri no 13 tahun 2006 dikenal dengan belanja tidak langsung dan belanja langsung. Selanjutnya dikatakan bahwa besarnya belanja ini sangat menentukan aktivitas perekonomian suatu daerah. Besarnya belanja pemerintah merupakan implementasi peran pemerintah daerah dalam mendorong kegiatan perekonomian daerah untuk meningkatkan kesejahteraan ekonomi masyarakat. Ini menunjukkan bahwa peran pemerintah sangat menentukan dalam pembangunan kesejahteraan ekonomi. 
Di sisi lain, faktor keuangan merupakan aspek esensial dalam mengukur tingkat kemampuan daerah dalam melaksanakan otonominya. Pemerintah Daerah pada umumnya tidak dapat melaksanakan fungsinya dengan efektif dan efisien tanpa biaya yang memadai untuk memberikan pelayanan dalam pembangunan. Hal ini sesuai dengan pendapat Pamuji (2003) dalam (Mangkuwinata \& Ikhsan, 2014) bahwa kemampuan keuangan merupakan faktor utama untuk mengetahui kemampuan daerah dalam mengurus rumah tangganya. Artinya dengan kondisi keuangan yang kuat maka belanja daerah akan meningkat dan selanjutnya akan berdampak pada perekonomian daerah. Kemampuan keuangan DKI Jakarta tergambar dari nilai APBD-nya sebagaimana diuraikan pada tabel berikut.

Tabel 1.

Struktur APBD Provinsi DKI Jakarta, 2006-2020 (Milyar Rupiah).

\begin{tabular}{clrrrrr}
\hline No & \multicolumn{1}{c}{ Subyek } & $\mathbf{2 0 1 6}$ & $\mathbf{2 0 1 7}$ & $\mathbf{2 0 1 8}$ & \multicolumn{1}{c}{$\mathbf{2 0 1 9}$} & \multicolumn{1}{c}{$\mathbf{2 0 2 0}$} \\
\hline 1 & Pendapatan & 56.944 .378 & 62.517 .744 & 65.809 .932 & 74.997 .497 & 82.195 .994 \\
2 & Belanja & 56.973 .170 & 61.821 .923 & 75.093 .831 & 77.857 .610 & 79.610 .435 \\
& a) Belanja Langsung & 30.805 .897 & 35.113 .383 & 41.012 .395 & 44.562 .631 & 44.935 .297 \\
& b) Belanja Tidak Langsung & 26.167 .273 & 26.708 .540 & 34.081 .436 & 33.294 .979 & 34.675 .138 \\
5 & Penerimaan Pembiayaan & 5.748 .790 & 9.305 .831 & 17.452 .307 & 11.895 .000 & 5.760 .154 \\
6 & Pengeluaran Pembiayaan & 5.719 .998 & 10.001 .652 & 8.168 .408 & 9.034 .887 & 8.345 .713 \\
7 & Total APBD & 62.693 .168 & 71.823 .575 & 83.262 .239 & 86.892 .497 & 87.956 .148 \\
\hline
\end{tabular}

Sumber: Diolah dari berbagai sumber, 2020

Berdasarkan pada Tabel 1, tampak bahwa pendapatan cenderung mengalami peningkatan dari tahun 2016 sampai dengan tahun 2020. Hal yang sama juga terjadi pada akun belanja langsung. Ini menunjukkan bahwa ada kecenderungan bahwa kenaikan pendapatan daerah diikuti dengan kenaikan belanja langsung. Dalam hal ini penerimaan pembiayaan dan pengeluaran pembiayaan selama periode 2016 sampai dengan 2020 nilainya bervariasi. Penerimaan pembiayaan nilai tertinggi terjadi pada tahun 2018, yaitu sebesar Rp17,45 triliun dan penerimaan pembiayaan terendah terjadi pada tahun 2016, yaitu sebesar Rp5,748 triliun. Pada pengeluaran pembiayaan tertinggi terjadi pada tahun 2017, yaitu sebesar Rp10,00 tirliun dan terendah terjadi pada tahun 2016 yaitu sebesar Rp5,719 triliun.

Mengingat APBD adalah dokumen publik maka proses penentuan besarnya pendapatan dan alokasi belanja dituntut untuk memenuhi prinsip governance, yaitu transparan, akuntabel. responsibel, indepdenden dan fairness. Berkaitan dengan perencanaan pembangunan daerah, penjelasan Sekretaris Daerah Pemeirntah Provinsi DKI Jakarta (Republika.co.id., 2019) bahwa Pemerintah Provinsi DKI Jakarta berusaha menjadi pemerintahan yang good governance, terbuka, transparan dan akuntabel. Pada setiap tahapan penyusunan Rancangan Anggaran Pendapatan dan Belanja Daerah (RAPBD) Tahun 2020 diproses secara professional, transparan dan terbuka. Untuk APBD tahun 2020, penyusunannya telah melalui sejumlah prosedur yang berpedoman pada Permendagri Nomor 33 Tahun 2019 tentang Pedoman Penyusunan Anggaran Pendapatan dan Belanja Daerah Tahun Anggaran 2020. Dokumen juga dipublikasikan melalui Portal http://bappeda.jakarta.go.id. Portal tersebut dapat diakses secara terbuka dan dapat diunduh secara bebas oleh publik. 
Menurut penelitian (Nugraheni, 2016) bahwa penyusunan e-budgeting mempunyai peran yang strategis. Pada aktivitas penyusunan anggaran dengan $e$ budgeting Pemerintah Provinsi DKI Jakarta telah terbantu terutama dalam mengefisiensikan realisasi APBD. Temuan ini menunjukkan bahwa proses penyusunan APBD di DKI Jakarta cukup transparan dan akuntabel dan dapat dipertanggungjawabkan setiap tahapannya.

Menurut Undang-Undang Nomor 33 tahun 2004 bahwa APBD terdiri dari pendapatan, belanja dan pembiayaan. Ketiga komponen ini saling berkaitan dan menentukan besarnya APBD suatu daerah. Oleh karena itu, pemerintahan daerah berkepentingan untuk melihat rincian masing masing komponen APBD tersebut. Besarnya APBD adalah penjumlahan total pendatapan dan penerimaan pembiayaan. Jumlah ini harus sama dengan jumlah total belanja daerah ditambah pengeluaran pembiayaan. Dengan demikian besarnya belanja sangat tergantung besarnya pendapatan. Semakin besar pendapatan akan semakin besar dana yang dapat dialokasikan untuk belanja guna pembangunan daerah.

Belanja mempunyai peran penting dalam memengaruhi perekonomian daerah. Selain besar belanja maka semakin besar Produk Domestik Regional Bruto daerah tersebut. Jumlah belanja daerah akan sangat terganutng dari jumlah pendapatannya. Menurut Nurain dan ABgio 2019 bahwa besarnya belanja berpaengaruh positf terhadap pertumbuahan ekonomi (Nuraini \& Mudakir, 2019). Dalam hal ini pemerintah daerah sanga berkepnatingan mementukan aloakskai belankak akerna pemeirntah derah bukan saja berfungsi untuk mengatur kegiatan perekonomian tetapi juga dapat memengaruhi tingkat belanja agreagat daerah.

Dengan demikian isu utama dalam penyusunan APBD adalah bagaimana alokasi belanja yang tepat dan sesuai dengan kebutuhan masyarakat. Jika alokasi belanja tepat maka akan mendorong pertumbuhan ekonomi. Pertumbuhan ekonomi ini penting karena pertumbuhan ekonomi merupakan salah satu indikator penilaian keberhasilan pelaksanaan pembangunan ekonomi daerah (Tumangkeng, 2018). Ini artinya bahwa perekonomian daerah akan berkembang jika pertumbuhan ekonomi daerah tersebut mengalami pertumbuhan ekonomi yang tinggi, stabil dan berkelanjutan.

Selain variabel investasi, peran kurs terhadap pertumbuhan ekonomi juga signifikan dan unik. Hal ini sesuai dengan hasil penelitian (Ismanto et al., 2019) bahwa variabel kurs mempunyai pengaruh yang signifikan terhadap pertumbuhan ekonomi. Oleh karena itu, pengelolaan kurs rupiah terhadap dolar Amerika Serikat menjadi penting. Di Indonesia sejak Agustus 1997, pemerintah memutuskan untuk mengganti sistem kurs mengambang terkendali (managed floating exchange rate system) menjadi sistem kurs mengambang bebas (free floating exchange rate system). Menurut (Arifin \& Mayasya, 2018) bahwa nilaI tukar rupiah terhadap dolar AS banyak dipengaruhi faktor fundamental dan non-fundamental. Yang termasuk faktor fundamental adalah tingkat inflasi, tingkat suku bunga, jumlah uang beredar serta arus kapital serta posisi neraca pembayaran. Sementara faktor nonfundamental antara lain faktor keamanan politik, stabilitas dalam negeri dan ketentraman masyarakat.

Menurut (Harahap, 2013), secara historis krisis nilai tukar yang terjadi di Indonesia tahun 1997 dimulai dari didevaluasinya mata uang Bath, Thailand. 
Dalam krisis ini dampaknya cukup serius terhadap nilai tukar rupiah terhadap Dolar Amerika. Kisaran tersebut berubah cukup dinamis dari kisaran Rp2.600 sampai dengan Rp14.900. Akibat dari situasi ini adalah para pelaku usaha yang menggunakan dolar Amerika mengalami tantangan dalam memenuhi kewajibankewajiban luar negeri yang jatuh tempo. Selain itu, juga dalam hal aktivitas impor bahan baku untuk produksi. Pada situasi ini juga ditandai dengan turunnya laju inflasi. Pada tahun 1996 sebelum krisis inflasi hanya 6,47\% menjadi 11,05\% pada tahun 1977, dan meningkat menjadi 77,6\% pada tahun 1998 dan inflasi turun menjadi $15 \%$ pada tahun 2000.

Kemajuan dan perkembangan teknologi informasi telah terbukti mendorong percepatan proses globalisasi termasuk globalisasi ekonomi. Karena hal ini, krisis keuangan menjadi lebih sering terjadi dan cepat menyebar ke daerah atau negara lain. Krisis ekonomi yang terjadi berpengaruh langsung terhadap indikator ekonomi termasuk pertumbuhan ekonomi. Menurut penelitian (Raz et al., 2012) bahwa selama krisis ekonomi, pertumbuhan ekonomi di wilayah Asia Timur termasuk Indonesia yang sebelum krisis pertumbuhan ekonominya relatif cepat menjadi negara yang pertumbuhan ekonominya menjadi negatif. Pertumbuhan ekonomi nasional yang seperti ini tentu memengaruhi pertumbuhan ekonomi Jakarta.

\section{METODE PENELITIAN}

Tipe penelitian yang digunakan adalah tipe deskriptif (descriptive research). Sedangkan analisisnya menggunakan deskriptif-kuantitatif. Selanjutnya analisis data dilakukan dengan metode regresi linier berganda yang membahas studi ketergantungan antara variabel dependen dengan variabel independent (Gujarati, 2013). Ini dimaksudkan untuk memperkirakan dan/atau memprediksi mean (populasi) atau nilai rata-ratanya terhadap nilai yang telah diketahui atau tetap (dari sampel). Adapun vaariabel yang digunakan meliputi

1. Pertumbuhan ekonomi adalah nilai kenaikan output/perubahan nilai riil berdasarkan PDRB Provinsi DKI Jakarta atas dasar harga konstan.

2. Rasio belanja barang modal yang dimaksud dalam penelitian ini adalah rasio alokasi belanja langsung yang terdiri dari belanja modal dan belanja barang dan jasa terhadap total belanja, yaitu belanja langsung dan belanja tidak langsung Pemerintah Provinsi DKI Jakarta.

a. Kelompok belanja tidak langsung adalah belanja yang dianggarkan tidak terkait secara langsung dengan pelaksanaan program dan kegiatan.

b. Kelompok belanja langsung adalah belanja yang dianggarkan terkait secara langsung dengan pelaksanaan program dan kegiatan

c. Belanja modal adalah belanja yang digunakan untuk pengeluaran yang dilakukan dalam rangka pembelian/pengadaan atau pembangunan aset tetap berwujud yang mempunyai nilai manfaat lebih dari 12 bulan untuk digunakan dalam kegiatan pemerintahan, seperti dalam bentuk tanah, peralatan dan mesin, gedung dan bangunan, jalan, irigasi dan jaringan, dan aset tetap. 
d. Belanja Barang dan Jasa adalah adalah belanja yang digunakan untuk pengeluaran pembelian/pengadaan barang yang nilai manfaatnya kurang dari 12 bulan dan/atau pemakaian jasa dalam melaksanakan program dan kegiatan pemerintahan daerah.

e. Belanja total adalah penjumlahan seluruh belanja yaitu belanja langsung dan belanja tidak langsung.

3. Nilai investasi adalah total nilai kegiatan penanaman modal baik langsung maupun tidak dengan harapan dapat mendapatkan sejumlah keuntungan dari hasil penanaman modal tersebut. Dalam penelitian ini didekati dengan nilai Pembentukan Modal Tetap Bruto (PMTB), yaitu pengeluaran untuk barang modal yang mempunyai umur pemakaian lebih dari satu tahun dan tidak merupakan barang konsumsi.

4. Nilai kurs adalah nilai tukar mata uang rupiah terhadap dolar Amerika Serikat. Menurut (Mankiw, 2015) nilai tukar atau sering dikenal dengan kurs antara dua negara adalah tingkat harga yang disepakati penduduk kedua negara untuk saling melakukan perdagangan.

5. Dummy variabel adalah variabel kualitatif yang telah dikodekan dan memiliki kuantifikasi dari variabel kualitatif dengan mempertimbangkan model yakni model intercept, slope, dan Kombinasi (Rahmadeni \& Dayusmar, 2017). Dalam hal ini kajian ini digunakan untuk menggambarkan dampak krisis ekonomi yang melanda Indonesia pada tahun 1998. Dalam hal ini tahun $1998=0$ Lainnya $=1$

Data yang digunakan dalam penelitian ini adalah data sekunder yang diperoleh dari berbagai sumber. Penelitian ini menggunakan data series untuk periode tahun 1987-2017. Sumber data adalah Badan Pusat Statistik (BPS) Provinsi DKI Jakarta, SKPD/UKPD yang ada di lingkungan pemerintah Provinsi DKI Jakarta, dan Bank Indonesia. Secara terinci data dimaksud adalah sebagai berikut.

Tabel 2.

Belanja, Investasi, PDRB dan Kurs di DKI Jakarta Periode 1987 - 2017

\begin{tabular}{crrrrrr}
\hline $\mathbf{( 1 )}$ & \multicolumn{1}{c}{$(\mathbf{2})$} & \multicolumn{1}{c}{$(\mathbf{3})$} & \multicolumn{1}{c}{$(\mathbf{4})$} & \multicolumn{1}{c}{$(\mathbf{5})$} & \multicolumn{1}{c}{$(\mathbf{6})$} & \multicolumn{1}{c}{$\mathbf{7})$} \\
\hline $1987-1992$ & 72,9 & 51,1 & 698,1 & $292,486.9$ & $477,643.9$ & $2,235.5$ \\
$1993-1997$ & 184,9 & 181,1 & $1.736,7$ & $352,868.9$ & $628,761.5$ & $2,730.2$ \\
1998 & 206,6 & 184,7 & $2.050,2$ & $268,165.5$ & $595,419.0$ & $8,025.0$ \\
1999 & 333,6 & 324,9 & $3.310,0$ & $275,104.4$ & $593,703.8$ & $7,100.0$ \\
$2000-2005$ & $1.754,2$ & $2.450,5$ & $8.988,7$ & $285,357.2$ & $704,050.2$ & $9,586.7$ \\
$2006-2010$ & $5.635,0$ & $4.220,4$ & 17.896 .0 & $427,375.9$ & $960,225.3$ & $9,556.0$ \\
$2011-2017$ & $11.807,4$ & $9.637,6$ & $38.715,6$ & $593,027.5$ & $1,381,392.6$ & $11,561.1$
\end{tabular}

Keterangan: (1) Tahun; (2) Belanja Barang/tahun (Milyar Rupiah); (3) Total Modal/tahun (Milyar Rupiah); (4) Total Belanja/tahun (Milyar Rupiah); (5) Investasi/tahun (Triliun Rupiah); (6) PDRB/tahun (Triliun Rupiah); (7) Kurs (Rp/\$US) Sumber: data diolah dari berbagai sumber, 2020.

Dalam penelitian ini model yang diajukan untuk mengetahui variabelvariabel yang memengaruhi pertumbuhan ekonomi di DKI Jakarta adalah sebagai berikut: 


$$
P E R T_{E K t}=\beta_{0}+\beta_{1} R M D L_{1 t}+\beta_{2} I N V_{2 t}+\beta_{3} K U R S_{3 t}+\beta_{4} D 98+u_{t}
$$

dimana

$$
\begin{array}{ll}
\mathrm{t} & =1,2,3, . . \mathrm{t} \\
\text { PERT_EK }_{\mathrm{t}} & =\text { Perumbuhan ekonomi (persen) } \\
\beta_{0} & =\text { Konstanta } \\
\mathrm{RMDL}_{\mathrm{t}} & =\text { Rasio belanja barang, jasa, dan modal terhadap total belanja } \\
\mathrm{INV}_{\mathrm{t}} & =\text { Nilai investasi (miliar rupiah) } \\
\text { KURS }_{\mathrm{t}} & =\text { Kurs Rp terhadap USD } \\
\text { D98 } & =\text { dummy krisis ekonomi } 1998(1998-1999=1,0=\text { lainnya) }
\end{array}
$$

Konstanta $\left(\beta_{0}\right)$ dalam persamaan regresi linier merupakan nilai variabel dependen $Y$ ketika semua peubah $\mathrm{X}_{\mathrm{i}}$ bernilai nol atau tidak mengalami perubahan. Dengan kata lain konstanta merupakan perpotongan antara sumbu variabel dependen dalam hal ini adalah pertumbuhan ekonomi dan sumbu variabel independen dalam hal ini adalah belanja daerah, investasi dan nilai kurs.

Selanjutnya untuk Uji Asumsi guna mendapatakan model yang baik selain uji statistik, juga dilakukan uji asumsi klasik. Uji asumsi klasik yang akan dilakukan dalam penelitian ini meliputi uji normalitas, uji multikolinieritas, uji heteroskedastisitas dan uji autokorelasi.

Uji Keberartian Model dilakukan dengan pendekatan melihat koefisien determinasi $\left(\mathrm{R}^{2}\right.$ ), overall test (uji F), dan partial test (uji t). Nilai $\mathrm{R}^{2}$ menunjukan berapa besar variasi dari semua variabel bebas dapat menjelaskan varaibel tidak bebasnya. Dalam hal ini seberapa besar variasi varabel rasio belanja barang dan modal, nilai investasi, dan nilai tukar rupiah terhadap dolar Amerika Serikat dapat menjelaskan variasi pertumbuhan ekonomi di DKI Jakarta.

Selanjutnya untuk mengetahui pengaruh variabel independen secara bersama sama digunakan uji $\mathrm{F}\left(\mathrm{F}_{\text {test }}\right)$. Uji $\mathrm{F}$ digunakan untuk melihat bagaimana pengaruh semua variabel bebas terhadap variabel terikat dan untuk menguji apakah model regresi yang ada signifikan atau tidak signifikan. Sementara uji t statistik untuk menguji bagaimana pengaruh masing-masing variabel bebasnya terhadap variabel terikatnya.

\section{HASIL DAN PEMBAHASAN}

\section{Kinerja Perekonomian DKI Jakarta}

Pembangunan di DKI Jakarta selama ini menunjukkan hasil yang menggembirakan yang ditandai dengan membaiknya berbagai indikator pembangunan. Data empiris menunjukkan bahwa pertumbuhan ekonomi DKI Jakarta cukup baik. Hal ini dapat dilihat pada Tabel berikut. 
Tabel 3.

PDRB Rata-rata Per Tahun dan Petumbuhan Ekonomi Periode 1987- 2017

\begin{tabular}{crr}
\hline TAHUN & $\begin{array}{c}\text { PDRB RATA- } \\
\text { RATA/TAHUN }\end{array}$ & PERTUMBUHAN \\
\hline $1987-1992$ & $477,643.9$ & $7.96 \%$ \\
$1993-1997$ & $628,761.5$ & $7.55 \%$ \\
1998 & $595,419.0$ & $-21.20 \%$ \\
1999 & $593,703.8$ & $-0.29 \%$ \\
$2000-2005$ & $704,050.2$ & $4.90 \%$ \\
$2006-2010$ & $960,225.3$ & $5.68 \%$ \\
$2011-2017$ & $1,381,392.6$ & $5.82 \%$ \\
\hline
\end{tabular}

Pada periode 1987-1992 rata-rata pertumbuhan ekonomi Jakarta per tahun mencapai 7,96 persen. Pada saat krisis, pada tahun 1998 pertumbuhan ekonomi minus 21,20 persen dan pada 1999 ekonomi Jakarta mulai membaik walaupun masih pada angka negatif, yaitu minus 0,29 persen. Sementara sejak tahun 2000 pertumbuhan perekonomian di DKI Jakarta relatif stabil di sekitar 5 persen.

Mencermati fenomena pertumbuhan ekonomi yang volatile ini tentunya memengaruhi perekonomian Jakarta secara keseluruhan. Agar fenomena ini dapat diketahui secara utuh maka diperlukan pengetahuan yang memadai terutama bagi para ASN yang bertugas sebagai salah satu penyusun utama kebijakan umum APBD.

\section{Perkembangan Belanja Daerah}

Berbeda dengan era sebelumnya bahwa pada era otonomi daerah, yatu pasca 1998 bahwa kebijakan alokasi belanja ini diperoleh melalui proses pelibatan seluruh pemangku kepentingan pembangunan, yaitu pemerintah, masyarakat, dan dunia usaha. Prosesnya pelibatan ini dilalui dengan cara proses politik, teknokratik, partisipatif, top down dan bottom up (Undang-Undang Nomor 25 Tahun, 2004). Hal ini didasarkan karena kebijakan pengeluaran pemerintah merupakan kebijakan publik yang secara langsung memengaruhi kepentingan masyarakat.

Untuk memenuhi kebutuhan pembangunan daerah diperlukan dana yang relatif besar. Kebijakan pemerintah daerah untuk pembangunan daerah direpresentasikan oleh besarnya alokasi belanja daerah. Dalam hal belanja daerah bahwa pada tahap awal perkembangan ekonomi alokasi belanja yang utama adalah menyediakan prasarana seperti pendidikan, kesehatan, prasarana transportasi dan sebagainya.

Dalam pembangunan daerah dibutuhkan belanja yang cukup besar. Besarnya belanja pembangunan baik belanja langsung maupun belanja tidak langsung sangat tergantung dari besarnya tingkat pendapatan daerah. Berdasarkan data empiris bahwa jumlah belanja Pemerintah Provinsi DKI Jakarta cenderung terus meningkat dan peningkatan ini cukup signifikan. Peningkatan ini dikarenakan jumlah pendapatan daerah cenderung meningkat. 
Data empiris menunjukkan bahwa pada periode 1987-2017 belanja Pemerintah Provinsi DKI Jakarta terus mengalami kenaikan, kecuali pada tahun 2008 dan 2014. Ini menunjukkan kemampuan keuangan Pemerintah Provinsi DKI Jakarta cenderung meningkat. Anggaran belanja tersebut digunakan untuk keperluan penyelenggaraan pemerintahan. pembangunan fisik. dan pembangunan non-fisik di wilayah Provinsi DKI Jakarta. Secara terinci data belanja pada tabel berikut.

Tabel 4.

Rerata Belanja Barang, Belanja Modal, dan Total Belanja Periode 1987- 2017 (Milyar Rupiah)

\begin{tabular}{crrr}
\hline \multirow{2}{*}{ TAHUN } & $\begin{array}{c}\text { RERATA PER TAHUN } \\
\text { BELANJA BARANG }\end{array}$ & $\begin{array}{c}\text { RERATA } \\
\text { BELANJA MODAL }\end{array}$ & $\begin{array}{c}\text { RERATA } \\
\text { TOTAL BELANJA }\end{array}$ \\
\hline $1987-1992$ & 72.9 & 51.1 & 698.1 \\
$1993-1997$ & 184.9 & 181.1 & $1,736.7$ \\
1998 & 206.6 & 184.7 & $2,050.2$ \\
1999 & 333.6 & 324.9 & $3,310.0$ \\
$2000-2005$ & $1,754.2$ & $2,450.5$ & $8,988.7$ \\
$2006-2010$ & $5,635.0$ & $4,220.4$ & $17,896.0$ \\
$2011-2017$ & $11,807.4$ & $9,637.6$ & $38,715.6$ \\
\hline \multicolumn{4}{c}{}
\end{tabular}

Dilihat jenis belanjanya, data empiris menyatakan bahwa terjadi perubahan drastis pada alokasi belanja Pemerintah Provinsi DKI Jakarta sejak tahun 2002. Perubahan drastis terjadi pada belanja barang dan jasa serta belanja modal. Sebelum tahun 2002, belanja lainnya memiliki porsi terbesar dalam alokasi belanja Pemprov DKI Jakarta. Namun sejak tahun 2002, belanja barang dan jasa serta belanja modal mengalami peningkatan tajam. Baik belanja barang dan jasa maupun belanja modal mempunyai porsi masing-masing sekitar 20 persen dari total belanja. Sementara untuk belanja lainnya hanya mempunyai alokasi sekitar 10 persen dari total belanja.

Mengingat dinamika perekonomian yang memengaruhi pendapatan daerah dan besarnya pendapatan daerah akan memengaruhi jumlah daerah belanja maka pencermatan dan pengkajian terhadap perekonomian menjadia penting. Berdasarkan data empirik tampak bahwa kecenderungan belanja daerah terus meningkat tetapi apakah hal ini memengaruhi tingkat pertumbuhan ekonomi daerah. Ini mungkin menjadi pertanyaan mendasar dan perlu menjadi perhatian bagi semua pemangku kepentingan proses penyusunan APBD DKI Jakarta, termasuk para ASN DKI Jakarta.

\section{Pergerakan Nilai Tukar Rupiah Terhadap Dolar Amerika}

Penyebab terjadinya fluktuasi nilai tukar rupiah terhadap dolar berasal dari berbagai faktor baik yang teknis ekonomi maupun non-teknis. Faktor-faktor tersebut antara lain jumlah uang beredar, harga, suku bunga, kondisi politik, kebijakan pemerintah, isu pembangunan dan lain-lain. 
Berdasarkan data empiris menyatakan bahwa nilai kurs rupiah terhadap dolar Amerika Serikat cenderung terdepresiasi. Data empiris berikut menyampiakan perkembangan nilai tukar rupiah terhadao dolar amreinteka serikat periode 1987 2017.

Tabel 5.

Nilai Kurs Rupiah Terhadap US Dolar Periode 1987 - 2017

\begin{tabular}{cc}
\hline TAHUN & KURS Rata-rata Rp/ \$ US \\
\hline $1987-1992$ & $2,235.5$ \\
$1993-1997$ & $2,730.2$ \\
1998 & $8,025.0$ \\
1999 & $7,100.0$ \\
$2000-2005$ & $9,586.7$ \\
$2006-2010$ & $9,556.0$ \\
$2011-2017$ & $11,561.1$ \\
\hline \multicolumn{2}{c}{ Sumber: Data diolah, 2020 }
\end{tabular}

Berdasarkan Tabel 1, bahwa nilai kurs rupiah terhadap dolar Amerika Serikat cenderung meningkat, rupiah terdepresiasi. Jika pada periode 1987-1992 nilai kurs pada kisaran Rp2.235,5 per satu dolar Amerika Serikat pada tahun 1998 dan 1999 kurs meningkat menjadi Rp8.025 dan Rp7.100 per dolar Amerika Seriktar berturutturut. Selanjutnya pada periode tahun 2011-2017 kurs pada kisaran Rp11.561 per dolar Amerika Serikat.

Walaupun demikian, mata uang rupiah dalam keadaan yang relatif stabil karena proyek pembangunan dan aktivitas ekonomi di Jakarta tetap berjalan dengan lancar walaupun beberapa hal memerlukan penyesuaian. Volatilitas nilai mata uang rupiah ini merupakan konsekuensi logis dari penerapan free floating exchange rate system, yaitu sistem nilai tukar mata uang mengambang terkendali.

Berkaitan dengan melonjaknya kurs sejak tahun 1997 merupakan isu yang perlu dibahas. Faktor-faktor yang memengaruhi terdepresiasinya kurs sejak pertengahan tahun 1997 antara lain adalah tidak stabilnya perekonomian mitra dagang dan bisnis, faktor inflasi yang tinggi, utang publik, kondisi stabilitas politik dan stabilitas cadangan devisa.

Hal ini berdampak pada terdepresiasinya nilai tukar adalah kinerja pertumbuhan ekonomi. Bagaimana hubungan nilai tukar dengan pertumbuhan ekonomi. Dengan kurs yang terdepresiasinya mendorong tingkat inflasi yang cukup tinggi. Hal ini terlihat bahwa pada masa krisis ekonomi tahun 1998 tingkat inflasi Jakarta cukup tinggi. Jika tingkat inflasi meningkat dan bisnis terganggu serta investasi terdampak sehingga masyarakat tidak suka memiliki uang tunai, karena nilai uang riil yang dipegang menjadi semakin rendah. Jika demikian mengakibatkan daya beli masyarakat menjadi rendah. Keadaan seperti ini mendorong para produsen tidak tertarik untuk melakukan produksi sebab hasil produksi kurang diterima pasar. Akibat selanjutnya adalah hasil produksi pun turun. Pada gilirannya dengan tingkat produksi yang menurun maka tingkat pertumbuhan ekonomi terdampak dan cenderung untuk menurun. 
Sama dengan variabel belanja daerah dan pertumbuhan ekonomi, variabel kurs rupiah terhadap dolar Amerika juga mempunyai volatilitas yang tinggi. Ini mengingat bahwa variabel kurs sangat dipengaruhi oleh variabel luar negeri dan dalam negeri. Pengalaman untuk mengelola nilai kurs menjadi penting dalam konteks ini. Untuk itulah diperlukan pengetahuan khusus berkaitan dengan karakteristik perekonomian Jakarta terutama para penentu pembangunan ekonomi Jakarta.

\section{Pergerakan Nilai Investasi di Jakarta}

Dalam penelitian ini, untuk variabel jumlah investasi di Jakarta digunakan dengan pendekatan nilai PMTB. Data empiris menunjukkan bahwa pertumbuhan nilai investasi di DKI Jakarta mengalami peningkatan yang cukup signifikan. Ini menunjukan bahwa iklim investasi di DKI Jakarta sangat kondusif. Nilai investasi di DKI Jakarta periode 1987-2017 adalah sebagai berikut.

\section{Tabel 6.}

Nilai Investasi Periode 1987 - 2017

(Triliun rupiah)

\begin{tabular}{cc}
\hline TAHUN & Investasi Rerata Per Tahun \\
\hline $1987-1992$ & $292,486.9$ \\
$1993-1997$ & $352,868.9$ \\
1998 & $268,165.5$ \\
1999 & $275,104.4$ \\
$2000-2005$ & $285,357.2$ \\
$2006-2010$ & $427,375.9$ \\
$2011-2017$ & $593,027.5$ \\
\hline \multicolumn{2}{c}{ Sumber: data diolah, 2020 }
\end{tabular}

Berdasarkan Tabel di atas, tampak bahwa nilai investasi di DKI Jakarta terus mengalami peningkatan. Ini menunjukkan bahwa Jakarta merupakan salah satu daerah tujuan investasi yang menarik. Hal ini merupakan kerja semua pemangku kepentingan dalam mewujudkan Jakarta sebagai kota pro investai.

Dalam perekonomian, investasi merupakan faktor yang sangat memengaruhi pertumbuhan ekonomi. Pertumbuhan ekonomi yang berkualitas akan meningkatkan kesejahteraan masyarakat. Namun perilaku investasi dan faktor yang memengaruhi tingkat investasi sangat komplek dari yang sifatnya teknik maupun non-teknis. Untuk itulah dalam kasus perekonomian Jakarta perlu pendekatan yang tepat. Bagi penyusun kebijakan ekonomi termasuk ASN DKI Jakarta hal ini perlu dikuasi dengan profesional. Salah satu pendekatan yang relevan adalah dengan model pembelajaran konstruktivistsik. Alsanya adalah bahwa pendekatan pembelajaran ini mendasarkan pada pengalaman peserta pelatihan dalam mengkontruksi pengetahuan. Sementara para ASN cukup banyak pengalaman dalam isu investasi sehingga pendekatan model konstruktivistik menjadi salah satu model pendekatan yang tepat. 


\section{Faktor-faktor yang Memengaruhi Pertumbuhan Ekonomi DKI Jakarta}

Determinan pertumbuhan ekonomi DKI Jakarta sangat variatif. Dalam kajian ini determinan pertumbuhan ekonomi didekati dengan faktor ekonomi, yaitu rasio belanja daerah, nilai investasi dan nilai tukar rupiah terhadap dolar Amerika Serikat.

Rasio belanja didekati dengan formula dengan rasio belanja antara jumlah belanja barang dan jasa, ditambah belanja modal terhadap total belanja (RMDL R . Nilai investasi dalam hal ini didekati dengan nilai Pembentukan Modal Tetap Bruto (PMTB) dan selanjutnya dilambngkan dengan $\mathrm{INV}_{\mathrm{t}}$ (Nilai investasi dalam miliar rupiah). Selanjutnya nilai tukar rupiah terhadap dolar Amerika Serikat yang pada prinsipnya adalah nilai rupiah per 1 dolar Amerika Serikat $\left(\mathrm{KURS}_{\mathrm{t}}\right)$. Selanjutnya untuk melihat pengharuh krisis ekonomi tahun 1998 didekati dengan variabel Dummy (D98). Dalam hal ini digunakan untuk tahun 1998-1999=1 sementara selain tahun tersebut $=0$.

Untuk mengetahui determinan yang berpengaruh terhadap pertumbuhan ekonomi di DKI Jakarta digunakan analisis regresi berganda dengan menggunakan software SPSS Versi 16. Adapun hasilnya adalah sebagai berikut.

PERT_EK $\mathrm{t}_{\mathrm{t}}=6,448+0,049 \mathrm{RMDL}_{\mathrm{t}}^{*}+0,00000721 \mathrm{INV}_{\mathrm{t}}{ }^{* * *}-0,001 \mathrm{KURS}_{\mathrm{t}}{ }^{* * *}-21,732 \mathrm{D98}^{* * *}$

$\mathrm{R}^{2}$-adj $=0,912$

DW $=1,942$

F-sig $=0,000$

* signifikan pada $\alpha 10 \%$

** signifikan pada $\alpha 5 \%$

Hasil selengkapnya ada pada Lampiran.1.

Hasil estimasi tersebut selanjutnya dilakukan pengujian berdasarkan kriteria ekonomi, statistik dan ekonometrika. Berdasarkan kriteria ekonomi, hasil estimasi parameter persamaan tersebut sesuai secara teori dan dapat dipertanggungjawabkan. Hal ini ditunjukkan dengan tanda dan besaran nilai estimasi parameter yang menggambarkan hubungan antara variabel dependen dengan variabel-variabel independen yang merupakan variabel penjelas.

Selanjutnya digunakan kriteria statistik untuk menguji persamaan yang telah disusun. Nilai koefisien determinasi $\left(\mathrm{R}^{2}\right)$ dari persamaan yang disusun cukup tinggi yaitu 0,912. Ini menunjukkan bahwa variabel-variabel penjelas (RMDL, INV, KURS, dan D98) yang digunakan dalam persamaan tersebut 91,2 persen dapat menjelaskan keragaman variabel pertumbuhan ekonomi di DKI Jakarta.

Sementara probabilita statistik uji-F yang dihasilkan untuk menguji apakah variabel-variabel penjelas yang digunakan berpengaruh nyata terhadap variabel dependennya bernilai 0,000 . Ini berarti variabel-variabel penjelas yang digunakan dalam model secara bersama-sama berpengaruh nyata terhadap pertumbuhan ekonomi di DKI Jakarta.

Uji parsial setiap variabel menggunakan statistik uji-t untuk menguji apakah suatu variabel penjelas secara individu berpengaruh terhadap variabel dependennya atau tidak. Hasil estimasi menunjukkan bahwa pada tingkat signifikansi 5 persen variabel nilai investasi, nilai tukar rupiah terhadap dolar Amerika Serikat dan krisis ekonomi 1998 signifikan berpengaruh terhadap pertumbuhan ekonomi di DKI 
Jakarta. Sementara rasio belanja barang dan modal signifikan memengaruhi pertumbuhan ekonomi pada tingkat signifikansi 10 persen.

Selain itu juga dilakukan uji asumsi klasik untuk mendapatkan model yang baik. Uji asumsi tersebut meliputi uji normalitas, uji multikolinieritas, uji homoskedastisitas dan uji autokorelasi. Hasil uji-uji tersebut menunjukkan model yang dihasilkan dapat diterima dan sesuai dengan asumsi-asumsi secara teroritis.

Proses mekanistis dalam konteks identifikasi variabel yang memengaruhi pertumbuhan ekonomi Jakarta menjadi penting untuk dicermati. Dengan mengetahui secara menyeluruh dan komprehensif tentang proses ini maka akan memudahkan penyusun kebijakan untuk menyusun kebijakan yang tepat dan menjadikan pertumbuhan ekonomi Jakarta lebih tinggi. Proses transformasi pengetahuan tentang proses identifikasi faktor yang memengaruhi pertumbuhan ekonomii kepada para penyusun kebijakan menjadi kebutuhan guna penyusunan kebijakan pembangunan daerah yang kondusif.

\section{Interpretasi Model}

Langkah selanjutnya dalam hal ini adalah penjelasan dan interpretasi model sebagaimana telah diuraikan di atas. Hasil analisis yang di representasikan dengan model dan hasil perhitungan adalah sebagai berikut.

PERT_EK $K_{\mathrm{t}}=6,448+0,049$ RMDL $_{\mathrm{t}}{ }^{*}+0,00000721 \mathrm{INV}_{\mathrm{t}}{ }^{* * *}-0,001 \mathrm{KURS}_{\mathrm{t}}{ }^{* *}-21,732$ D98 $^{* *}$

Dalam hal ini variabel rasio belanja barang dan jasa dan modal terhadap total belanja dalam analisis mempunyai koefisien 0,049 dan hubungannya positif serta mempunyai signifikansi a 10 persen. Ini mempunyai pengertian bahwa hubungan positif RMDL terhadap pertumbuhan ekonomi di DKI Jakarta. Nilai koefisien 0,049 menunjukkan bahwa peningkatan RMDL sebesar 1 persen cateris paribus, akan meningkatkan laju pertumbuhan ekonomi di DKI Jakarta sebesar 0,049 persen.

Variabel Investasi dan dalam hal ini koefisien variabel investasi (INV) didekati dengan nilai Pembentukan Modal Tetap Bruto (PMTB) mempunyai tanda sesuai teori yaitu positif dan signifikan pada level 5 persen. Kondisi ini mempunyai pengertian bahwa terdapat hubungan positif peningkatan investasi terhadap peningkatan pertumbuhan ekonomi di DKI Jakarta. Nilai koefisien 0,00000721 menunjukkan bahwa peningkatan Investasi sebesar Rp1 triliun ceteris paribus, akan meningkatkan laju pertumbuhan ekonomi di DKI Jakarta sebesar 0,007 persen.

Dalam konteks investasi, jumlah investasi yang masuk ke Jakarta tentu dipengaruhi oleh berbagai faktor baik yang sifatnya global, regional maupun nasional. Hal ini mengingat bahwa Jakarta merupakan pusat aktivitas perekonomian nasional, pusat aktivitas bisnis dan keuangan internasional. Untuk itulah diperlukan analisis yang komprehensif dan holistik untuk mengenali faktor yang memengaruhi pertumbuhan ekonomi Jakarta.

Hasil analisis variabel nilai tukar rupiah terhadap dolar Amerika Serikat (KURS) dalam analisis ini diperoleh hasil sesuai dengan konsep ekonomi. Koefisien variabel nilai tukar rupiah terhadap dolar Amerika Serikat (KURS) mempunyai tanda sesuai teori ekonomi, yaitu negatif dan signifikan pada $\alpha=5 \%$. 
Hal ini mempunyai pengertian bahwa terdapat hubungan negatif variabel nilai tukar rupiah terhadap dolar Amerika Serikat dengan peningkatan pertumbuhan ekonomi di DKI Jakarta dengan nilai koefisien sebesar 0,001. Hal ini seperti yang ditunjukkan oleh hasil penelitian (Syamsuyar \& Ikhsan, 2017) bahwa nilai tukar rupiah terhadap dolar yang direpresntasikan dengan rupaiah per dolar Amerika Serikat pengaruhnya positif dan signifikan terhadap pertumbuhan ekonomi. Selanjutnya ditemukan juga bahwa perubahan sistem nilai tukar mengambang terkendali ke sistem nilai tukar mengambang yang bebas menunjukkan pengaruh negatif dan signifikan terhadap pertumbuhan ekonomi.

Selanjutnya variabel krisis ekonomi tahun 1998 yang direpresentasikan dengan variabel dummy (D98) berpengaruh negatif terhadap pertumbuhan ekonomi Jakarta. Dalam hal ini tingkat signifikansinya adalah 5 persen. Dengan kata lain bahwa krisis ekonomi tahun 1998 yang dimulai di pertengahan 1997 dan puncaknya pada tahun 1998 berpengaruh negatif dan signifikan terhadap penurunan pertumbuhan ekonomi di DKI Jakarta.

\section{Krisis Ekonomi dalam Perekonomian Jakarta}

Data empiris membuktikan bahwa krisis tahun 1997 telah meruntuhkan pondasi perekonomian nasional. Dalam waktu kurang dari satu tahun nilai tukar rupiah terhadap dolar Amerika Serikat merosot drastis dan menembus nilai sekitar Rp15.000 per 1 dolar AS. Hal ini membawa implikasi cukup luas. Hutang pemerintah dan swasta menjadi tinggi dan mendorong permintaan agregat domestik terus menurun sampai dengan pertengahan 1998. Akibat lainnya adalah jumlah pengangguran meningkat dan mencapai sekitar 14,1 juta orang. Aspek lain dari krisis ekonomi ini adalah menandakan bahwa struktur perekonomian Indonesia masih belum kokoh. Kondisi ini sesuai dengan hasil penelitian Sari dan Fakhruddin (2016) bahwa krisis tahun 1997-1998 sangat memengaruhi nilai tukar, suku bunga, rasio pembayaran utang, dan inflasi.

Krisis ekonomi Jakarta sangat terpengaruh dampaknya. Pertumbuhan ekonomi terkontraksi, inflasi juga membumbung tinggi. Kondisi demikian memengaruhih pendapatan daerah. Dengan pendapatan daerah yang semkian menurun karena lesunya kegiatan ekonomi dan bisnis mengakibaatkan jumlah belanja daerah juga mernurun. Perekonomian Jakarta sangat dipengaruhi stabilitas perekonomian nasional secara keseluruhan. Pada masa stabil dan normal perekonomian Jakarta kecenderungannya lebih tinggi dari perekonomian nasional. Hal ini sebagaimana juga dikemukaan oleh Menteri PPN.Kepala Bappenas (Bappenas.go.id, 2019) (Bappenas.go.id, 2019) bahwa laju pertumbuhan ekonomi Provinsi DKI Jakarta dalam lima tahun terakhir selalu tumbuh cukup jauh di atas laju pertumbuhan ekonomi nasional. Ini merupakan prestasi dan sangat membantu perekonomian nasional, terlepas dari hal tersebut bahwa pada masa krsisis pertumbuhan ekonomi Jakarta di bawah pertumbuhan ekonomi nasional.

Sejalan dengan fenomena magnitude laju pertumbuhan ekonomi, magnitude laju inflasi juga searah. Jika masa krisis laju inflasi Jakarta cenderung lebih rendah dari laju inflasi tingkat nasional. Sementara jika dalam kondisi normal dan stabil laju tingkat inflasi Jakarta cenderung lebih tinggi dibanding tingkat inflasi nasional. Magnitude dari arah pergerakan indikator perekonomian makro Jakarta dan 
nasional menjadi salah satu informasi yang sangat berharga dalam perencanaan pembangunan baik dalam lingkup nasional maupun dalam lingkup pembangunan daerah. Hal ini tentunya dapat menjadi salah satu masukan bagi pemutus kebijakan dalam menyusun kebijakan.

\section{E. SIMPULAN}

Pertumbuhan ekonomi di DKI Jakarta pada periode 1987-2017 cenderung pada pergerakan yang positif. Krisis ekonomi tahun 1998 dan 1999 telah mengoreksi pertumbuhan ekonomi Jakarta. Berdasarkan perhitungan bahwa pada tahun 1998 pertumbuhan ekonomi Jakarta minus 21,20 dan tahun 1999 minus 0,29 persen. Sejak tahun 2000 sampai 2017 pertumbuhan ekonomi Jakarta di kisaran 5 persen.

Rasio belanja barang, jasa dan modal terhadap total belanja Pemerintah Provinsi DKI Jakarta dan investasi secara signifikan mempunyai pengaruh positif terhadap pertumbuhan ekonomi di DKI Jakarta. Sementara depresiasi nilai tukar rupiah terhadap dolar Amerika Serikat yang terjadi dalam perekonomian Indonesia mempunyai pengaruh negatif terhadap pertumbuhan ekonomi Jakarta. Dalam hal variabel krisis ekonomi ditemukan bahwa variabel ini mempunyai pengaruh negatif terhadap pertumbuhan ekonomi Jakarta.

Krisis ekonomi secara nasional telah berpengaruh langsung terhadap perekonomian Jakarta. Jika dalam masa krisis pertumbuhan ekonomi Jakarta lebih rendah dari laju pertumbuhan ekonomi nasional. Sebaliknya jika pada masa normal dan stabil laju pertumbuhan ekonomi Jakarta lebih tinggi dibanding dengan laju pertumbuhan ekonomi nasional.

Kepada TAPD (Tim Aggaran Pemerintah Daerah) yang dipimpin oleh Sekretaris Daerah agar mengalokasikan belanja daerah dengan proporsi belanja langsung lebih besar dari belanja tidak langsung. Selain itu, kepada TAPD juga agar menginstruksikan kepada Satuan Kerja Perangkat Daerah yang mengelola investasi daerah untuk memberikan iklim yang kondusif dalam investasi. Untuk implementasi hal ini diperlukan ASN DKI Jakarta yang berkualitas agar pembangunan ekonomi Jakarta tepat sasaran dan lebih berkualitas terutama berkaitan dalam penyusunan APBD. 


\section{DAFTAR PUSTAKA}

Arifin, S., \& Mayasya, S. (2018). Faktor - Faktor Yang Memengaruhi Nilai Tukar Rupiah Terhadap Dolar Amerika Serikat. Jurnal Ekonomi-Qu, 8(1), 82-96.

Bappenas.go.id. (2019). Musrenbangprov DKI Jakarta: Menteri Bambang Dorong Perekonomian DKI Jakarta Lebih Tinggi dengan Investasi. Bappenas.go.id.

Fajri, A. (2016). Pengaruh belanja modal terhadap pertumbuhan ekonomi provinsiprovinsi di Sumatera. Faculty of Economics and Business, University of Jambi, 5(1), 29-35.

Ginting, A. M., \& Dewi, G. P. (2013). Pengaruh Pertumbuhan Ekonomi Dan Pertumbuhan Sektor Keuangan Terhadap Pengurangan Kemiskinan Di Indonesia ( The Influence of Economic Growth and Financial Sector on Poverty Alleviation in Indonesia ). Jurnal Ekonomi Dan Kebijakan Publik, 4(2), 117-130.

Gujarati, N. D. (2013). Basic Econometrics (5th ed.). International Edition Mc Graw Hill.

Harahap, S. R. (2013). Deteksi Dini Krisis Nilai Tukar Indonesia: Identifikasi Periode Krisis Tahun 1995 - 2011. Economics Development Analysis Journal, 2(4), 318-328.

Ismanto, B., Rina, L., \& Kristini, M. A. (2019). Pengaruh Kurs Dan Impor Terhadap Pertumbuhan Ekonomi Indonesia PERIODE TAHUN 2007- 2017. Ecodunamika, 3(2).

Kurniawan, D., Pamuji, T., \& Hayati, T. N. (2015). Penerapan Model Solow-Swan Untuk Memacu Pertumbuhan Ekonomi Kabupaten Demak. Media Ekonomi Dan Manajemen., 30(1), 68-71.

Mangkuwinata, \& Ikhsan, S. M. (2014). Analisis Penerimaan Dan Pengeluaran Pemerintah Kabupaten Bireuen. Jurnal Kebangsaan, 3(6), 24-34.

Mankiw, N. G. (2015). Macroeconomics (9th ed.). worth publisher.

Natalia, N. D. A., Rumate, V. A., \& Tolosang, K. D. (2019). Pengaruh Belanja Modal dan Belanja Sosial Pemerintah terhadap Pertumbuhan Eekonomi di Sulawesi Utara. Jurnal Berkala Ilmiah Efisiensi, 19(3), 97-106.

Nugraheni, L. K. (2016). Analisis Proses Penyusunan E-Budgeting Pemerintah Provinsi Dki Jakarta. Jurnal Ilmiah Universitas Bakrie.

Nuraini, R., \& Mudakir, B. (2019). Analisis Pengaruh Keterbukaan Ekonomi Terhadap Pertumbuhan Ekonomi (Studi Kasus: Asean Tahun 2007 - 2017). Jurnal Dinamika Ekonomi Pembangunan, 2(2), 20-35.

Peraturan Menteri Dalam Negeri Nomor 13. (2006). Tentang Pedoman Pengelolaan Keuangan Daerah.

Pridayanti, A. (2014). Pengaruh Ekspor, Impor, dan Nilai Tukar terhadap Pertumbuhan Ekonomi di Indonesia Periode 2002-2012. Jurnal Pendidikan Ekonomi, Universitas Negeri Surabaya, 2(2).

Rahmadeni, \& Dayusmar, D. (2017). Analisis Produksi Hasil Perkebunan di Kabupaten Kampar dengan Menggunakan Dummy Variable. Jurnal Sains Matematika Dan Statistika, 3(1), 64-69.

Raz, A., Indra., T. P. K., Artikasih., D. K., \& Citra, S. (2012). Krisis Keuangan Global Dan Pertumbuhan Ekonomi: Analisa Dari Perekonomian Asia Timur. 
Buletin Ekonomi Moneter Dan Perbankan, 37-56.

Republika.co.id. (2019). Pemprov DKI Janji Transparansi RAPBD 2020 https://nasional.republika.co.id/berita/pz7oil282/pemprov-dki-janjitransparansi-rapbd-2020.

Https://Nasional.Republika.Co.Id/Berita/Pz7oil282/Pemprov-Dki-JanjiTransparansi-Rapbd-2020.

Sari, P. K., \& Fakhruddin. (2016). Identifikasi Penyebab Krisis Moneter Dan Kebijakan Bank Sentral Di Indonesia: Kasus Krisis Tahun (1997-1998 dan 2008). Jurnal Ilmiah Mahasiswa (JIM), 1(2), 377-388.

Syamsuyar, H., \& Ikhsan. (2017). Dampak Sistem Nilai Tukar Terhadap Pertumbuhan Ekonomi Indonesia. Jurnal Ilmiah Mahasiswa (JIM Ekonomi Pembangunan Fakultas Ekonomi Dan Bisnis Unsyiah, 2(3), 414-422.

Tumangkeng, S. (2018). Analisis Potensi Ekonomi Di Sektor Dan Sub Sektor Pertanian, Kehutanan Dan Perikanan Kota Tomohon. Jurnal Berkala Ilmiah Efisiensi, 18(1), 127-138.

Undang - Undang Nomor 17 Tahun. (2003). Tentang Keuangan Negara.

Undang - Undang Nomor 25 Tahun. (2004). Tentang Sistem Perencanaan Pembangunan Nasional.

Wahyuni, G. A. P., Sukarsa, M., \& Yuliami, N. (2014). Pengaruh Pengeluaran Pemerintah dan Investasi terhadap Pertumbuhan Ekonomi dan Kesenjangan Pendapatan Kabupaten/Kota di Provinsi Bali. Jurnal Ekonomi Dan Bisnis Universitas Udayana, 3(8), 458-477.

Widada, R., Hakim, D. B., \& Mulatsih, S. (2014). Analisis Pertumbuhan Ekonomi Kabupaten/Kota Hasil Pemekaran Di Indonesia. Jurnal Manajemen Pembangunan Daerah, 6(2), 1-15.

Zuhroh, L. H. (2018). Analisis Pengaruh Aset Daerah Dan Belanja Modal Terhadap Produk Domestik Regional Bruto Di Koridor Utara Selatan Provinsi Jawa Timur. Jurnal Ilmu Ekonomi, 2(2), 241-250. 


\section{Lampiran. 1. Hasil Output SPSS}

\section{Regression}

\begin{tabular}{llll}
\multicolumn{4}{c}{ Variables Entered/Removed(b) } \\
\hline \multirow{4}{*}{ Model } & \multicolumn{1}{c}{ Variables } & Variables & \\
\hline 1 & Entered & Removed & Method \\
\hline & D98, & & \\
& KURS, & & \\
& INV, & & Enter \\
& RMDL(a) & & \\
\hline
\end{tabular}

a All requested variables entered.

b Dependent Variable: PERT_EK

Model Summary(b)

\begin{tabular}{lrrrrr}
\hline Model & R & R Square & Adjusted R Square & Std. Error of the Estimate & Durbin-Watson \\
\hline 1 &, $961($ a) &, 923 &, 912 & 1,41086 & 1,942 \\
\hline a Predictors: (Constant), D98, KURS, INV, RMDL \\
b Dependent Variable: PERT_EK
\end{tabular}

ANOVA(b)

\begin{tabular}{|c|c|c|c|c|c|c|}
\hline \multicolumn{2}{|c|}{ Model } & \multirow{2}{*}{$\frac{\text { Sum of Squares }}{623,983}$} & \multirow{2}{*}{$\frac{\mathrm{df}}{4}$} & \multirow{2}{*}{$\begin{array}{r}\text { Mean Square } \\
155,996\end{array}$} & \multirow{2}{*}{$\frac{F}{78,370}$} & \multirow{2}{*}{$\frac{\text { Sig. }}{\text {,000(a) }}$} \\
\hline 1 & Regression & & & & & \\
\hline & Residual & 51,753 & 26 & 1,991 & & \\
\hline & Total & 675,737 & 30 & & & \\
\hline
\end{tabular}

Coefficients(a)

\begin{tabular}{|c|c|c|c|c|c|c|c|c|}
\hline \multirow{2}{*}{\multicolumn{2}{|c|}{ Model }} & \multicolumn{2}{|c|}{$\begin{array}{l}\text { Unstandardized } \\
\text { Coefficients } \\
\text { Std. }\end{array}$} & \multirow{2}{*}{$\begin{array}{c}\text { Standardized } \\
\text { Coefficients } \\
\text { Beta }\end{array}$} & \multirow[b]{2}{*}{$\mathrm{t}$} & \multirow[b]{2}{*}{ Sig. } & \multicolumn{2}{|c|}{$\begin{array}{c}\text { Collinearity } \\
\text { Statistics }\end{array}$} \\
\hline & & B & $\begin{array}{l}\text { Std. } \\
\text { Error }\end{array}$ & & & & Tolerance & VIF \\
\hline \multirow[t]{5}{*}{1} & (Constant) & 6,448 &, 781 & & 8,256 & 000 & & \\
\hline & RMDL & 049 & ,029 & 189 & 1,709 & 099 & 240 & 4,166 \\
\hline & INV & $\begin{array}{r}7,21 \mathrm{E}- \\
006\end{array}$ &, 000 & ,210 & 2,700 & ,012 & ,485 & 2,061 \\
\hline & KURS &,- 001 &, 000 &,- 541 & $-5,049$ & ,000 & 257 & 3,896 \\
\hline & D98 & $-21,723$ & 1,569 &,- 822 & $13,846^{-}$ & ,000 & ,836 & 1,197 \\
\hline
\end{tabular}




\section{Collinearity Diagnostics(a)}

\begin{tabular}{llrrrrrrr}
\hline & & & Condition & \multicolumn{4}{c}{ Variance Proportions } & \\
Model & Dimension & Eigenvalue & \multicolumn{1}{c}{ Index } & (Constant) & RMDL & INV & KURS & D98 \\
\hline 1 & 1 & 3,813 & 1,000 &, 01 &, 00 &, 00 &, 00 &, 00 \\
& 2 &, 980 & 1,972 &, 00 &, 00 &, 00 &, 00 &, 81 \\
& 3 &, 138 & 5,257 &, 42 &, 03 &, 01 &, 14 &, 01 \\
& 4 &, 040 & 9,741 &, 53 &, 04 &, 98 &, 08 &, 03 \\
& 5 &, 029 & 11,557 &, 05 &, 92 &, 01 &, 78 &, 15 \\
\hline
\end{tabular}

a Dependent Variable: PERT_EK

Residuals Statistics(a)

\begin{tabular}{lrrrrr}
\hline & Minimum & Maximum & Mean & Std. Deviation & N \\
\hline Predicted Value & $-17,4897$ & 8,8609 & 5,7199 & 4,56064 & 31 \\
Residual & $-5,19756$ & 2,06874 &, 00000 & 1,31344 & 31 \\
Std. Predicted Value & $-5,089$ &, 689 &, 000 & 1,000 & 31 \\
Std. Residual & $-3,684$ & 1,466 &, 000 &, 931 & 31 \\
\hline a Dependent Variable: PERT_EK & & & & &
\end{tabular}


Lampiran. 2. Belanja, Investasi, Kurs DKI Jakarta Periode 1987- 2017

\begin{tabular}{|c|c|c|c|c|c|c|c|}
\hline TAHUN & $\begin{array}{c}\text { Belanja } \\
\text { Barang } \\
\text { (Milyar } \\
\text { Rp) }\end{array}$ & $\begin{array}{c}\text { Belanja } \\
\text { Modal } \\
\text { (Milyar } \\
\text { Rp) }\end{array}$ & $\begin{array}{c}\text { Total } \\
\text { Belanja } \\
\text { (Milyar } \\
\text { Rp) }\end{array}$ & $\begin{array}{c}\text { Investasi } \\
\text { (Triliun } \\
\text { Rp) }\end{array}$ & $\begin{array}{c}\text { PDRB } \\
\text { (Triliun Rp) }\end{array}$ & $\begin{array}{l}\text { Pertumbuhan } \\
\text { Ekonomi (\%) }\end{array}$ & $\begin{array}{c}\text { KURS } \\
\text { (Rp/US } \\
\$ \text { ) }\end{array}$ \\
\hline 1987 & 30.6 & 10.2 & 337.8 & $173,314.2$ & $321,510.5$ & & $1,661.7$ \\
\hline 1988 & 32.0 & 22.7 & 395.5 & $187,761.6$ & $342,772.7$ & $6.20 \%$ & $1,740.9$ \\
\hline 1989 & 41.9 & 27.8 & 476.7 & $229,598.0$ & $376,152.4$ & $8.87 \%$ & $1,820.0$ \\
\hline 1990 & 47.8 & 44.6 & 594.0 & $258,056.0$ & $411,721.9$ & $8.64 \%$ & $1,901.0$ \\
\hline 1991 & 92.7 & 69.8 & 770.4 & $290,559.3$ & $449,089.8$ & $8.32 \%$ & $1,992.0$ \\
\hline 1992 & 119.7 & 80.7 & 916.1 & $323,145.7$ & $486,972.0$ & $7.78 \%$ & $2,062.0$ \\
\hline 1993 & 122.1 & 99.5 & $1,104.5$ & $324,105.8$ & $530,315.1$ & $8.17 \%$ & $2,110.0$ \\
\hline 1994 & 145.9 & 141.6 & $1,399.6$ & $323,597.6$ & $575,960.2$ & $7.93 \%$ & $2,200.0$ \\
\hline 1995 & 199.9 & 187.4 & $1,806.7$ & $350,166.6$ & $629,331.8$ & $8.48 \%$ & $2,308.0$ \\
\hline 1996 & 226.1 & 240.1 & $2,081.1$ & $391,051.0$ & $686,570.7$ & $8.34 \%$ & $2,383.0$ \\
\hline 1997 & 230.4 & 236.9 & 2,291.6 & $375,423.7$ & $721,629.8$ & $4.86 \%$ & $4,650.0$ \\
\hline 1998 & 206.6 & 184.7 & $2,050.2$ & $268,165.5$ & $595,419.0$ & $-21.20 \%$ & $8,025.0$ \\
\hline 1999 & 333.6 & 324.9 & $3,310.0$ & $275,104.4$ & $593,703.8$ & $-0.29 \%$ & $7,100.0$ \\
\hline 2000 & 383.6 & 323.0 & 3,997.9 & $266,776.4$ & $619,429.6$ & $4.15 \%$ & $9,595.0$ \\
\hline 2001 & $1,080.1$ & $2,194.9$ & $6,856.7$ & $238,438.4$ & $648,644.4$ & $4.50 \%$ & $10,400.0$ \\
\hline 2002 & $1,352.7$ & $3,152.9$ & $8,754.2$ & $243,180.1$ & $680,371.1$ & $4.66 \%$ & $8,940.0$ \\
\hline 2003 & $2,173.1$ & $2,754.1$ & $10,382.6$ & $330,472.0$ & $716,451.9$ & $5.04 \%$ & $9,465.0$ \\
\hline 2004 & $2,607.8$ & $2,872.2$ & $11,493.3$ & $300,601.2$ & $756,947.2$ & $5.35 \%$ & $9,290.0$ \\
\hline 2005 & $2,927.9$ & $3,406.0$ & $12,447.6$ & $332,675.0$ & $802,457.1$ & $5.67 \%$ & $9,830.0$ \\
\hline 2006 & $3,444.0$ & $4,209.3$ & $15,175.5$ & $342,377.7$ & $850,169.5$ & $5.61 \%$ & $9,020.0$ \\
\hline 2007 & $5,382.6$ & $4,251.3$ & $17,284.1$ & $400,694.1$ & $904,916.3$ & $6.05 \%$ & $9,419.0$ \\
\hline 2008 & $5,255.7$ & $2,581.6$ & $15,956.5$ & $460,365.9$ & $961,314.4$ & $5.87 \%$ & $10,950.0$ \\
\hline 2009 & $6,773.2$ & $4,816.6$ & $19,511.1$ & $454,598.5$ & $1,009,543.0$ & $4.78 \%$ & $9,400.0$ \\
\hline 2010 & 7,319.6 & $5,243.1$ & $21,552.9$ & $478,843.2$ & $1,075,183.5$ & $6.11 \%$ & $8,991.0$ \\
\hline 2011 & $8,341.8$ & $7,316.3$ & $26,423.6$ & $512,541.4$ & $1,147,558.2$ & $6.31 \%$ & $9,068.0$ \\
\hline 2012 & $11,685.9$ & $8,784.4$ & $33,541.2$ & $575,221.8$ & $1,222,527.9$ & $6.13 \%$ & $9,670.0$ \\
\hline 2013 & $12,641.4$ & $10,696.0$ & $38,301.5$ & $583,200.7$ & $1,296,694.6$ & $5.72 \%$ & $11,708.8$ \\
\hline 2014 & $12,624.4$ & $10,411.1$ & $37,798.6$ & $601,887.0$ & $1,373,389.1$ & $5.58 \%$ & $11,879.5$ \\
\hline 2015 & $10,633.8$ & $10,244.0$ & $41,585.0$ & $607,162.1$ & $1,454,345.8$ & $5.57 \%$ & $11,879.5$ \\
\hline 2016 & $13,062.7$ & $8,965.5$ & $45,920.0$ & $616,589.6$ & $1,539,376.7$ & $5.52 \%$ & $13,307.3$ \\
\hline 2017 & $13,662.1$ & $11,045.7$ & $47,439.2$ & $654,590.0$ & $1,635,855.8$ & $5.90 \%$ & $13,414.4$ \\
\hline
\end{tabular}

